University of Michigan Law School

University of Michigan Law School Scholarship Repository

\title{
Why Was the U.S. Corporate Tax Enacted in 1909?
}

\author{
Reuven S. Avi-Yonah \\ University of Michigan Law School
}

Available at: https://repository.law.umich.edu/book_chapters/209

Follow this and additional works at: https://repository.law.umich.edu/book_chapters

Part of the Antitrust and Trade Regulation Commons, and the Taxation-Federal Commons

\section{Publication Information \& Recommended Citation}

Avi-Yonah, Reuven S. "Why Was the U.S. Corporate Tax Enacted in 1909?" In Studies in the History of Tax Law, edited by J. Tiley, vol. 2, 377-92. Portland, Oreg.: Hart Pub., 2007.

This Book Chapter is brought to you for free and open access by the Faculty Scholarship at University of Michigan Law School Scholarship Repository. It has been accepted for inclusion in Book Chapters by an authorized administrator of University of Michigan Law School Scholarship Repository. For more information, please contact mlaw.repository@umich.edu. 


\title{
14 \\ Why was the US Corporate Tax Enacted in 1909?
}

\author{
REUVEN S AVI-YONAH*
}

\begin{abstract}
This chapter argues that the principal reason the US adopted the corporate tax in 1909 was to regulate corporate managerial power, and that in this regard the 1909 tax differed both from the 1894 corporate tax and from current conceptions of the tax as an indirect tax on corporation's shareholders.

The United States has had a corporate income tax since 1909. Currently, this tax is under significant criticism, with several academics and practitioners calling for its abolition. It therefore seems appropriate in this context to try to determine what led to the enactment of this tax, and whether the original motivation can shed some light on the current debate on whether the tax should be retained. ${ }^{1}$
\end{abstract}

\section{ANTECEDENTS: AGGREGATE-BASED TAXATION BEFORE 1909}

HE FIRST FEDERAL income tax, enacted to raise revenues during the Civil War, did not tax corporations, although a withholding tax was imposed on dividends and interest paid by railroad corporations and financial institutions, as well as on amounts added to surplus. ${ }^{2}$ Instead, under the 1864 version of the tax, 'the gains and profits of all companies,

* This chapter is based in part on R.S. Avi-Yonah, 'The Story Behind the Separate Corporate Income Tax' in S. Bank and K. Stark (eds.), Business Tax Stories (Foundation Press, New York, 2005). I would like to thank the participants of the 2004 tax history colloquium at Cambridge University, and especially John Tiley and Steve Bank, for their help with this project.

1 This chapter addresses only the first question (why the tax was enacted in 1909); for an argument on the second question (why the tax should be retained) see R.S. Avi-Yonah, 'Corporations, Society and the State: A Defense of the Corporate Tax' (S.2004). 90 Virginia L Rev 1193.

${ }^{2}$ Act of 1 July 1862 , ch. 119, $\mathbb{S} 81-82,12$ Stat. 432, 469-470 (repealed 1874). Shareholders and bondholders were permitted to exclude dividends and interest subject to withholding from income: ibid., at $\$ 91,12$ Stat. 473-474 (repealed 1874). 
whether incorporated or partnership, other than the companies specified in this section, shall be included in estimating the annual gains, profits, or income of any person entitled to the same, whether divided or otherwise'. ${ }^{3}$ The Civil War income tax thus included a form of pass-through taxation that applied to corporations, and the imposition of the tax on the undivided profits of corporations was specifically upheld by the Supreme Court. ${ }^{4}$

Pass-through treatment of corporate profits reflected the aggregate view of the corporation prevalent at the time. ${ }^{5}$ It also reflected the fact that most corporations were small, closely-held enterprises, and therefore (like today) it was relatively easy to identify the shareholders and to tax them on corporate profits. For those enterprises that were more widely held, like railroads, a withholding tax collected by the corporation effectively replaced the tax on the shareholder. ${ }^{6}$

The Civil War version of the income tax was allowed to expire with the end of reconstruction in 1872.7 In 1894, after the financial panic of 1893 and the economic dislocation that followed, the Democrats in Congress were able to pass an income tax bill. ${ }^{8}$ The debate at the time focused on the protective tariff, which was the main source of revenue for the federal government. ${ }^{9}$ The tariff functioned as a highly regressive consumption tax, and benefited the manufacturing centres of the Northeast at the expense of the more agricultural South and West. ${ }^{10}$ The Democrats argued that relying solely on tariffs allowed the newly super-rich railroad, steel and sugar magnates to escape any meaningful tax burden. ${ }^{11}$ Their argument was further bolstered by the fact

3 Act of 30 June 1864, ch. 173, $\mathbb{1} 117,13$ Stat. 223, 281-282 (repealed 1874). Also under this Act, a withholding tax was imposed on dividends and interest paid by certain types of corporations, and such dividends and interest payments were excluded from income: ibid., at $\mathbb{S} \mathbb{S}$ 120-122, 13 Stat. at 283-285 (repealed 1874).

${ }^{4}$ Collector $v$ Hubbard 79 US (12 Wall.) 1, 18 (1870).

5 See M.J. Horwitz, 'Santa Clara Revisited: The Development of Corporate Theory'(1985) 88 WVa. L Rev. 173, 183-186.

${ }^{6}$ Note, however, that this was not a perfect replacement since the corporate rate was $5 \%$ with no exemption whereas the top shareholder rate was $10 \%$ with a US\$600 exemption. See S.A. Bank,' Entity Theory as Myth in the Origins of the Corporate Income Tax' (2001) 43 Wm \& Mary L. Rev. 447, at 457-458. The decision to treat the withholding tax as the final tax in the case of widely-held enterprises presumably reflected the practical difficulty of collecting tax on a pass-through basis in those cases: ibid., at 522-524.

7 W.E. Brownlee, 'Historical Perspective on U.S. Tax Policy Toward the Rich' in J.B.Slemrod (ed.), Does Atlas Shrug? The Economic Consequences of Taxing the Rich (Harvard UP, Cambridge, Mass., 2000)29, 35; D.J. Ventry Jr., 'Equity Versus Efficiency and the U.S. Tax System in Historical Perspective' in J.J. Thorndike and D.J. Ventry Jr (eds).,Tax Justice: The Ongoing Debate (Urban Institute Press, Washington, DC, 2002)25, 29; S.R. Weisman, The Great Tax Wars: Lincoln to Wilson-The Fierce Battles Over Money and Power That Transformed the Nation (Simon \& Schusler, New York, 2002)101.

${ }^{8}$ Brownlee, above n. 7, at 37; Ventry, above n. 7, at 30; Weisman, above n. 7, at 131-146.

${ }^{9}$ Brownlee, above n. 7, at 37; Ventry, above n. 7, at 29-30; Weisman, above n. 7 at 138.

10 Weisman, above n. 7 , at 138 .

11 Weisman, above n. 7 , at 136-138. 
that the state-level personal property taxes were notoriously ineffective in reaching intangible forms of property, such as stocks and bonds. ${ }^{12}$

The 1894 Act for the first time imposed a tax of 2 per cent on the net income of all 'corporations, companies, or associations doing business for profit in the United States, no matter how created or organized, but not including partnerships'. ${ }^{13}$ At first impression this appears to be a stark departure from the Civil War income tax, which taxed corporate income in the hands of the shareholders and employed withholding at the corporate level only as a collection device. However, Steven Bank has convincingly demonstrated that such a reading of the 1894 Act is misleading. ${ }^{14}$ First, he points out that dividends from taxable corporations were excluded from shareholder income, so that the corporate tax could be viewed as a collection device for the shareholder-level tax (imposed at the same rate). ${ }^{15}$ Secondly, the House version of the 1894 Act followed the Civil War income tax in imposing a withholding tax on dividends and interest, except that the tax was also applied to undistributed income and to all corporations. ${ }^{16}$ Thus, the progression from the Civil War income tax to the House bill to the final version of the 1894 Act can be seen as a gradual process of modifying what was fundamentally a withholding tax imposed on the shareholders. ${ }^{17}$ Thirdly, the Congressional debates on the 1894 Act show that the principal motive for the corporate-level tax was to reach the shareholders, most of whom were precisely the kind of rich individuals who were able to escape the state-level personal property tax and whose corporations benefited from the high tariffs. ${ }^{18}$ And finally, Bank points out that the norm throughout the latter half of the nineteenth century was for most corporations to distribute their net earnings out as dividends. ${ }^{19}$ In that context, imposing a withholding tax on dividends was the most effective way to tax shareholders in widely-held enterprises, and imposing the same tax on additions to surplus was merely another enforcement device to prevent accumulated income from escaping tax. By 1894, the withholding tax was transformed into a tax on all the income of the corporation (distributed or not), but was still seen primarily as a device to tax shareholders. ${ }^{20}$

12 Ventry, above n. 7, at 29-30.

13 Tariff Act of 1894, ch. 349, $\mathbb{S} 32,28$ Stat. 509, 556 (held unconstutitional in Pollock $v$ Farmer's Loan \& Trust Co., 157 US. 429, aff'd and modified on reh'g, 158 US 601 (1895)).

${ }_{14}$ Bank, above n. 6, at 504-537.

15 Ibid., at 462 (citing Tariff Act of 1894, ch. 349, $\mathbb{2 8} 28$ Stat. 509, 554). Integration was incomplete because corporations were not eligible for the $\$ 4,000$ exemption: see ibid., at $462-463$, but this can be explained by administrative convenience.

1626 Cong. Rec. 6831 (1894).

17 Bank, above n. 6, at 517-519.

18 Ibid., at 530.

19 Ibid., at 528-529.

20 Ibid. at 530-531. 
Thus, throughout the nineteenth century, there was little evidence at the federal level of direct taxation of corporations as such. Withholding taxes were imposed at the corporate level on both distributed and undistributed income, but those were seen as an indirect way of taxing shareholders, consistently with the aggregate view of the corporation.

\section{THE 1909 ACT: A REAL ENTITY MEASURE}

In 1895, the Supreme Court struck down the 1894 Act as an unconstitutional direct tax without apportionment. ${ }^{21}$ The Democrats immediately made reinstatement of the income tax a major plank of their platform for the 1896 and 1900 elections, but to no avail. ${ }^{22}$ With the decisive victory of William McKinley (author of the notorious McKinley tariff of 1890) and his corporate allies in 1896, the income tax issue seemed dead. ${ }^{23}$

The situation changed with the rise of the Progressives and the accession of Theodore Roosevelt to the White House in 1901. Roosevelt spent his seven years in office greatly expanding the powers of the federal government vis-à-vis corporations. He was the first President to attempt to use the Sherman Antitrust Act, adopted in 1890 but left largely unused until his time, to break up the great monopolies, such as John D. Rockefeller's Standard Oil Company. ${ }^{24}$ In addition, he established the Bureau of Corporations to assemble information on, and ultimately perhaps to regulate, corporations. ${ }^{25} \mathrm{He}$ also proposed that all corporations should be incorporated under the authority of the federal government. ${ }^{26}$

On the tax front, Roosevelt expressed support in 1907 (after another financial panic) for a graduated income tax, but supporters of the tariff within the Republican Party were able to delay consideration of the issue until after the 1908 election. ${ }^{27}$ The newly-elected President Taft was less of a supporter of the income tax than his predecessor, and was worried about enacting another tax that would be found to be unconstitutional. ${ }^{28}$ However, he was also faced with increased support for the income tax in Congress and a possible split within his own party between Northeastern opponents of the

21 Pollock v Farmers' Loan \& Trust Co, 157 US 429, aff'd and modified on reh'g, 158 US 601 (1895).

22 Brownlee, above n. 7, at 37- 38; Weisman, above n. 7, at 165-172.

23 Weisman, above n. 7, at 175-177.

24 United States v N Sec Co, 193 US 197 (1904); Standard Oil Co v United States, 221 US 1 (1911).

25 Act of 14 1903, ch. 552, $\mathbb{S}$ 6, 32 Stat. 825, 827-828 (codified as amended in scattered sections of 15 USC).

${ }_{26}$ M.E. Kornhauser, 'Corporate Regulation and the Origins of the Corporate Income Tax'(1990) 66 Ind LJ 53, 66 See discussion immediately below.

27 Weisman, above n. 7, 203-205.

28 Ibid. at 211. 
tax and Midwestern supporters. ${ }^{29}$ Eventually, Taft proposed a compromise: Enact a corporate excise tax measured by income, which could withstand judicial scrutiny, and simultaneously submit an amendment to the Constitution to permit enactment of an income tax. ${ }^{30}$

The legislative debate on the proposed tax was set in the broader context of the debate on tariff reduction. Opponents of tariff reduction, mostly from Northeastern states, viewed high tariffs as essential to protecting American industry, and argued that the benefits of such tariffs extended to ordinary workers as well as to captains of industry. ${ }^{31}$ Proponents of tariff reduction, mostly from the West and the South, argued that high tariffs raised the price of goods consumed by ordinary Americans to benefit the rich. ${ }^{32}$

Initially, it seemed likely that the tariff bill (named after its co-sponsors the Payne-Aldrich Tariff) would be enacted by the Republican majority in both houses. In the House, income tax proponents like Cordell Hull (Democrat,Tennessee.) were unable to attach an income tax amendment to the tariff bill. In the Senate, however, progressive Republicans like Robert La Follette (Wisconsin.) and Democrats like Joseph Bailey (Texas) were more effective in arguing for the income tax. La Follette and Bailey argued that since the rich benefited more than the poor from government protection, they should pay more for it, and that enacting the income tax would silence the 'envious voice of anarchy' (socialism). ${ }^{33}$

Ultimately, Senator Nelson Aldrich (Republican, Rhode Island), the main opponent of the income tax, realised that with 19 Republicans threatening to join the Democrats and vote for the income tax, he might lose. ${ }^{34}$ In a crucial meeting at the White House, Aldrich and Taft agreed to support instead a corporate tax plus a constitutional amendment empowering Congress to levy the income tax, while maintaining high tariffs. ${ }^{35}$ Aldrich stated, 'I shall vote for a corporation tax as a means to defeat the income tax.' 36 This compromise ultimately passed the Senate by 45 votes to 34 and the House by 195 votes to 183, and was signed into law by the President on 5 August 1909. ${ }^{37}$

The 1909 Act imposed 'a special excise tax with respect to the carrying on or doing business' of 1 per cent of net income over $\$ 5,000$ of 'every corporation, joint stock company or association, organized for profit' under US law, and every foreign corporation engaged in business in the United

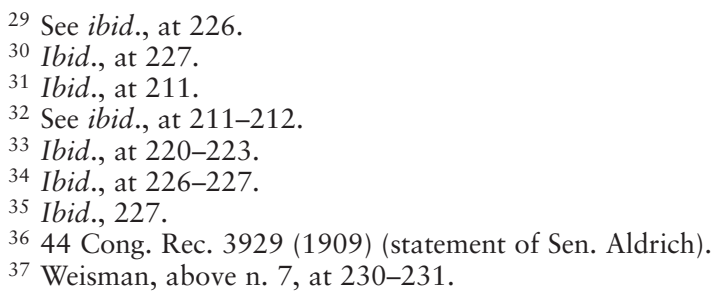


States. ${ }^{38}$ Dividends from taxable corporations were excluded from corporate income. ${ }^{39}$

What was the rationale for the 1909 Act, which is the origin of our current corporate income tax? Proponents of the tax gave several reasons, including the benefits theory and viewing the corporate tax as an indirect tax on shareholders. ${ }^{40}$ However, as Marjorie Kornhauser has pointed out, a major motive for the act was to regulate corporations. ${ }^{41}$ The principal vehicle for regulation was the filing of tax returns, which were to be made public. ${ }^{42}$ But more broadly, the tax itself fulfilled a potential regulatory function-it could serve as a vehicle to restrict the accumulation of power in the hands of corporate management. ${ }^{43}$

The various motives for enacting the corporate tax, which reflect the three theories of the corporation, can be seen in President Taft's message to Congress and in the debate that preceded enactment in the Senate. President Taft's message of 16 June 1909 gives three reasons for enacting a corporate tax (rather than a general income tax, which may be unconstitutional, or an inheritance tax, which did not have sufficient political support among Republicans in the Senate). ${ }^{44}$ The first reason is that ' $[\mathrm{t}]$ his is an excise tax upon the privilege of doing business as an artificial entity and of freedom from a general partnership liability enjoyed by those who own the stock' ${ }^{45}$ This argument is clearly based on an artificial entity view of the corporation as a creature of the state. However, Taft was aware that it is difficult to make this argument for a federal tax when the privileges enjoyed by the corporation derived from state law. ${ }^{46}$ The reason he made the argument nevertheless was that this formulation was necessary to ensure the tax's constitutionality, since the Supreme Court had upheld such an excise tax on sugar and oil companies in the Spreckels case. ${ }^{47}$ Taft added that nevertheless the tax 'accomplishes the same purpose as a corporation income tax'. ${ }^{48}$

The second argument made by Taft was that the corporate tax imposes a burden at the source of the income at a time when the corporation is well able to pay and when collection is easy. ${ }^{49}$ The reference to collection 'at the source' relates to the aggregate view of the corporation, since the tax is viewed as a withholding tax imposed on the shareholders (referred to at the

38 Tariff Act of 1909 , ch. 6, $\mathbb{S} 38,36$ Stat. 11, 112-113 (codified as amended in scattered sections of 19 USC).

39 Ibid., 36 Stat. at 112.

40 See discussion of Congressional debate below, nn. 130-154 and accompanying text.

41 Kornhauser, above note 26, at 53.

42 See discussion of publicity below, nn.140-144 and accompanying text.

43 See discussion of regulatory function below, nn. 145-149.

44 See Weisman, above n. 7, at 227.

4544 Cong. Rec. 3344 (1909) (statement of Pres. Taft).

46 See discussion of benefits argument in the Senate, below.

47 Spreckels Sugar Ref. Cov McClain 192 US 397 (1904), cited in Cong. Rec., above n.45.

48 Ibid.

49 Ibid. 
time as 'stoppage at source'). ${ }^{50}$ This is similar to the mainstream modern view of the tax, although the reference to the corporations' ability to pay (as opposed to the shareholders') has a real entity overtone. Taft probably did not emphasise the nature of the tax as an indirect tax on shareholders because that would have made it more suspect to the opponents of the income tax as well as more vulnerable to a constitutional challenge.

Instead, the principal reason Taft gave for enacting a corporate tax was the third one-that it would enable the federal government to exercise some degree of supervision, primarily by obtaining information about the business affairs of corporations. Taft devoted a whole paragraph of his message to this argument, much more than he gave to the first two. He stated the following:

Another merit of this tax is the federal supervision which must be exercised in order to make the law effective over the annual accounts and business transactions of all corporations. While the faculty of assuming a corporate form has been of the utmost utility in the business world, it is also true that substantially all of the abuses and all of the evils which have aroused the public to the necessity of reform were made possible by the use of this very faculty. If now, by a perfectly legitimate and effective system of taxation, we are incidentally able to possess the Government and the stockholders and the public of the knowledge of the real business transactions and the gains and profits of every corporation in the country, we have made a long step toward that supervisory control of corporations which may prevent a further abuse of power. ${ }^{51}$

This remarkable paragraph rests on the real entity view of the corporation as separate from both the state and the shareholders. It identifies corporate management as the source of 'abuse of power' and suggests that the imposition of the corporate tax will enable the government, the shareholders and the public to obtain information that will serve as the basis for restricting such managerial abuses of power. While the tax itself is incidental to the regulatory mechanism, this statement is important because it delineates a reason to tax corporations that is unrelated to the tax on shareholders or to the benefits conferred by the state. The tax is imposed on corporations because of the power exercised by corporate management, and management is clearly regarded as distinct from the shareholders (who will in fact be beneficiaries of the supervision over management actions). ${ }^{52}$

50 Bank, above n. 6, at 517.

51 Cong. Rec., above n. 45.

52 Similarly, in a letter dated 27 June 1909, Taft identified the publicity feature as a particularly important element of the tax, stating that 'publicity gives a kind of federal supervision over corporations, which is quite a step in the direction of similar reforms I am going to recommend at the next session of Congress': Letter from William Howard Taft to Horace Taft 8 (27 June 27 1909), in Papers of William Howard Taft (Library of Congress, Manuscript Division, Reel 497), cited in Kornhauser, above n. 6, at 99. 


\section{Reuven S Avi-Yonah}

The same mixture of motives can also be seen in the Congressional debate over enactment. Proponents and opponents of the tax reflected all three theories of the corporation. Some viewed it primarily as a benefits tax, ${ }^{53}$ others primarily as a tax on the shareholders. ${ }^{54}$ However, the predominant strain in the debate was to view the tax as a regulatory device to restrict abuses of managerial power.

The artificial entity view of the tax was expressed primarily by those proponents who sought to defend it from a constitutional attack. ${ }^{55}$ Senator Root, for example, who was one of the main drafters of the bill, defended the tax in part as based on the privilege of limited liability. ${ }^{56}$ Opponents, however, were quick to point out that since corporations were created under state law, the federal government had no right to tax them under an artificial entity view. ${ }^{57}$ In addition, opponents pointed out that unincorporated businesses obtained from the federal government the same benefits as corporations. ${ }^{58}$

The aggregate view was advanced by proponents who argued that the corporate tax was an indirect way to tax wealthy shareholders. ${ }^{59}$ Opponents argued that the tax did not discriminate between wealthy and less wealthy shareholders. ${ }^{60}$ Proponent Senator Cummins stated that ' $[\mathrm{s}] \mathrm{o}$ far as taxes are concerned, corporations are mere trustees for their shareholders; and their shareholders must pay the tax' ${ }^{61}$ Others argued that the tax would be shifted to consumers or wage earners, at least by the strongest corporations in the best position to avoid competition-the trusts. ${ }^{62}$

53 See below.

54 See below.

55 See, eg, 44 Cong. Rec. 4237 (1909) (statement of Sen. Daniel) (describing a corporation as an artificial entity and defending the constitutionality of a tax on it).

5644 Cong. Rec. 4006 (1909).

57 'The United States did not create these corporations . . . I should like to know whether there is on the part of any Member of the Senate a belief that the Congress . . can, through the medium of taxation, destroy the corporations that have been created by the several states?': 44 Cong. Rec. 3977 (1909) (statement of Sen. Cummins).

58 'I deny the right of Congress to levy a tax upon the business of corporations as such .... It is an arbitrary [classification]; it is an unfair one . . . [I]t is a tax upon the right to do business as a corporation as distinguished from the right to do business as an individual or as a copartnership': 44 Cong. Rec. 3976 (1909) (statement of Sen. Cummins).

59 See below.

60 'Shall we levy an income tax upon the stockholders of all corporations for pecuniary profit, without respect or regard to the extent of the income earned or enjoyed by those stockholders . . . ?': 44 Cong. Rec. 3955 (1909) (statement of Sen. Cummins); see also 44 Cong. Rec. 4008 (1909) (statement of Sen. Clapp) (similar).

6144 Cong. Rec. 3975 (1909) (statement of Sen Cummins). See also Kornhauser, above n. 26, at 94 ('Obviously a tax on the corporation is really a tax upon its stockholders, for otherwise than as a matter of legal reasoning a corporation and its stockholders are one') (quoting Bureau of Corporations, Taxation of Corporations: New England (US Government Washington, DC, 1909)5-6i.

62 See 44 Cong. Rec. 3985-3987 (1909) (statement of Sen. Borah). Senator Cummins likewise considered that the tax may be shifted from shareholders: 44 Cong. Rec. 3975 (1909) (statement of Sen. Cummins), as did Senator Clapp: 44 Cong. Rec. 4008 (1909) (statement of Sen. Clapp). 
But by far the most significant debate centered on the real entity view of the corporation and the argument that the tax was a regulatory device. Some of this debate centered on the publicity feature of the tax, but some of it understood the tax as a preliminary measure to control and limit managerial power directly. For example, Senator Flint (a supporter of the $\operatorname{tax}$ ) stated that 'it would give a certain amount of control of corporations by the National Government, publicity as to the condition of the affairs of corporations, and supervision to a certain extent over those corporations'. ${ }^{63}$ Publicity was part of the regulatory scheme, but not the only part.

The publicity feature was stressed by many. Senator Dixon, for example, stated that he favoured the tax primarily because of the publicity feature, for he feared the tax itself would not reach wealthy shareholders. ${ }^{64}$ Senator Newlands likewise supported the tax as 'securing, through publicity and otherwise, such supervisory control by the National Government as can be constitutionally exercised over corporations'. ${ }^{65}$ Even Senator Aldrich, the ultra-conservative chair of the Finance Committee, supported the publicity feature. ${ }^{66}$ Senator Cummins, who opposed the tax, nevertheless supported the publicity feature because the 'revolution in industry' resulting from the rise of large corporations 'is simply a prelude to industrial commercial slavery unless the Government intervenes with its strong arm, and it can not intervene unless it has the information necessary to enable it to act intelligently and wisely'. ${ }^{67}$

Other Senators, however, emphasised the potential of the tax directly to limit managerial power. Senator Newlands stated, 'I favor also present legislative action imposing an excise tax in such form as to reach the great accumulated wealth of the country, or its earnings, engaged in corporate enterprise. ${ }^{68}$ Nor did he mean by this indirect taxation of wealthy shareholders, because he went on to state that 'there was no reason why the great combinations monopolizing these industries [protected by the tariff] should not pay some part of the national expenses as well as the masses of the people

6344 Cong. Rec. 3937 (1909) (statement of Sen. Flint).

6444 Cong. Rec. 3941 (1909) (statement of Sen. Dixon); see also 44 Cong. Rec. 4001 (1909) (statement of Sen. Bourne) (favouring of the publicity feature) ('I personally concur with the President that the corporation net-earnings tax, in view of the publicity feature incident to it, is of infinitely greater importance and will be far more beneficial to this country than either the inheritance or income tax.').

6544 Cong. Rec. 3756 (1909) (statement of Sen. Newlands); see also 44 Cong. Rec. 3759 (1909) (statement of Sen. Newlands) ('securing information which would enable Congress to act intelligently in future with reference to taxation, the regulation of industrial combinations, and the imposition of tariff duties.')

66 See 44 Cong. Rec. 3930 (1909) (statement of Sen. Aldrich); see also 44 Cong. Rec. 4006-4007 (1909) (statement of Sen. Root) (supporting the publicity feature).

6744 Cong. Rec. 3965 (1909) (statement of Sen. Cummins).

6844 Cong. Rec. 3756 (1909) (statement of Sen. Newlands). 
who use and consume [their products]'. ${ }^{69}$ Newlands thus viewed the tax as falling on the accumulated wealth in the hands of the corporation itself, that is, upon corporate management. ${ }^{70}$ Senator Owen likewise spoke of the 'enormous volume of corporate wealth': '[t]he most important need of the people of the United States of this generation requires the abatement of the gigantic fortunes being piled up by successful monopoly, . . . which have brought about a grossly inequitable distribution of the proceeds of human labor. ${ }^{71}$ Like other Democrats, he would have preferred an income or inheritance tax, but supported the corporate tax for its direct potential impact on corporatethat is, managerial-wealth.

Senator Root, a principal draftsman of the tax, and personal friend of the President, likewise emphasised the potential of the tax to reach the wealth accumulated in the hands of corporate management, because he favoured taxing such wealth over earned income:

Mr. President, it has so happened that in the development of the business of the United States the natural laws of trade have been making the distinction [between earned and unearned income] for us, and they have put the greater part of the accumulated wealth of the country into the hands of corporations, so that when we tax them we are imposing the tax upon the accumulated income and relieving the earnings of the men who are gaining a subsistence for their old age and for their families after them. ${ }^{72}$

Opponents of the tax also stressed the regulatory aspect, but suggested that it had the potential of giving the federal government too much power over corporations. For example, Senator Cummins, stated:

If this tax is intended not to create a revenue, but if it is intended for the purpose of supervising and regulating corporations, that is quite a different proposition. I should like to know before we get through with this whether it is proposed through this tax to impose supervisory regulations upon all the corporations of the United States . . .You know there is just a little intimation in the message of the President that that is the end which is finally to be reached ... I think that before

6944 Cong. Rec. 3761 (1909) (statement of Sen. Newlands); see also 44 Cong. Rec. 3762 (1909) (statement of Sen. Newlands) ('Justice demands that the various forms of manufactured wealth, in whose favor the taxing power of the Nation is so freely exercised, should make some substantial contribution to the national expenses ...').

7044 Cong. Rec. 4048-4049, 4233 (1909) (statement of Sen. Newlands) (advocating a tax concentrated on the management of the great trusts, and exempting small corporations); 44 Cong. Rec. 4229-4230 (1909) (statement of Sen. Dolliver) (similar).

7144 Cong. Rec. 3950 (1909) (statement of Sen. Owen).

7244 Cong. Rec. 4003 (1909) (statement of Sen. Root); see also 44 Cong. Rec. 4006 (1909) (statement of Sen. Root) (distinguishing between earned income and 'accumulated capital' which should be taxed). Senator Cummins argued that the corporate tax would not achieve this purpose since it would fall on all shareholders, rather than just on management: 44 Cong. Rec. 4038 (1909) (statement of Sen. Cummins). 
the Government of the United States enters upon the work of supervising and regulating all those corporations . . . we had better stop and think a while. ${ }^{73}$

Cummins, however, was not opposed to all federal regulation through the corporate tax, just to a tax that indiscriminately applied to all corporations, as opposed to the proper targets-the great trusts:

If we can regulate our corporations simply through the medium of taxation, we can destroy every trust in a fortnight. It would be a great deal better for the Finance Committee to turn its attention to the imposition of such a tax upon corporations and the persons who actually need regulation, who are exercising powers that are injurious to the American people, destroying competition and invading our prosperity, than to attempt to levy a revenue tax upon all the little shareholders of all the little corporations throughout the length and breadth of the United States. ${ }^{74}$

Other opponents of the tax likewise supported regulating the large trusts through taxation, referring to the excise tax imposed on the gross income of the sugar and oil trusts in $1898 .{ }^{75}$ They opposed the proposed corporate tax, however, because it exempted dividends received from other taxable corporations from the tax base, thereby encouraging the formation of holding companies-precisely those companies that formed the legal basis for the trusts. ${ }^{76}$ Proponents of the tax replied that it was better to attack the trusts via a tax on all corporations than to refrain from attacking them at all. ${ }^{77}$

\section{SUMMARY}

We thus see that between 1894 and 1909 a significant change occurred in regard to the justification for the corporate tax. The 1894 tax was conceived as a continuation of the Civil War tax, that is, as a withholding tax on shareholders. The 1909 tax, on the other hand, while still seen by some opponents as an indirect tax on shareholders, was primarily viewed as a regulatory device to restrict managerial power. This goal was achieved most

7344 Cong. Rec. 3978 (1909) (statement of Sen. Cummins); see also 44 Cong. Rec. 4047 (1909) (statement of Sen. Hughes) (arguing that regulation should be done directly).

7444 Cong. Rec. 3978 (1909) (statement of Sen. Cummins). Cummins argued that much higher rates would drive the trusts out of business: 44 Cong. Rec. 4232 (1909) (statement of Sen. Cummins).

7544 Cong. Rec. 4009 (1909) (statement of Sen. Clapp).

7644 Cong. Rec. 4010 (1909) (statement of Sen. Clapp); 44 Cong. Rec. 4230 (1909) (statement of Sen. Dolliver). Senator Aldrich replied that this was necessary to avoid double corporate taxation and that no for-profit corporation was exempt from tax: 44 Cong. Rec. 4231 (1909) (statement of Sen. Aldrich).

7744 Cong. Rec. 4036 (1909) (statement of Sen. Davis). 
directly through the publicity feature of the tax, but both proponents and opponents also saw the tax as having the potential to regulate management directly by reducing corporate wealth and therefore restricting managerial power.

This shift can easily be discerned by comparing two Supreme Court opinions dealing with the corporate tax. In 1870 the Court decided that the Civil War income tax may be applied to tax shareholders upon the undivided profits of a corporation. ${ }^{78}$ Fifty years later the Court held that a shareholder may not be taxed on a stock dividend distributed by a corporation since that would be tantamount to taxing her on the undistributed income of the corporation, which is not her income under the Sixteenth Amendment. ${ }^{79}$ The Court stated:

We have no doubt of the power or duty of a court to look through the form of the corporation and determine the question of the stockholder's right, in order to ascertain whether he has received income taxable by Congress without apportionment. But, looking through the form, we cannot disregard the essential truth disclosed; ignore the substantial difference between corporation and stockholder; treat the entire organization as unreal; look upon stockholders as partners, when they are not such; treat them as having in equity a right to a partition of the corporate assets, when they have none; and indulge the fiction that they have received and realized a share of the profits of the company which in truth they have neither received nor realized. We must treat the corporation as a substantial entity separate from the stockholder, not only because such is the practical fact but because it is only by recognizing such separateness that any dividend-even one paid in money or property — can be regarded as income of the stockholder. Did we regard corporation and stockholders as altogether identical, there would be no income except as the corporation acquired it; and while this would be taxable against the corporation as income under appropriate provisions of law, the individual stockholders could not be separately and additionally taxed with respect to their several shares even when divided, since if there were entire identity between them and the company they could not be regarded as receiving anything from it, any more than if one's money were to be removed from one pocket to another. ${ }^{80}$

Thus, by 1920, the Court viewed the corporation as a real entity separate and distinct from the shareholders 'because such is the practical fact'. ${ }^{81}$ The same real entity view underlay most, although not all, of the arguments made when the corporate tax was adopted in 1909.

78 Collector v Hubbard 79 US (12 Wall.) 1, 18 (1870).

79 Eisner $v$ Macomber 252 US 189 (1920).

80 Ibid., at 213-214. The Court then went on to state that Hubbard was overruled by Pollock v Farmers' Loan \& Trust Co157 US 429, aff'd and modified on reh'g, 158 US 601 (1895), and was not reinstated by the Sixteenth Amendment: 252 US at 218-219.

81 Ibid., at 214. The other argument advanced by the Court-that cash dividends could not be taxed-interestingly ignores the fact that between 1913 (when the Sixteenth Amendment was adopted and the first individual income tax adopted) and 1936, cash dividends were to 
What accounts for the change between 1894, when the corporate tax was seen as a withholding device and the aggregate view was dominant, and 1909, when the real entity view was the main reason for adopting a corporate tax? The principal reason is a significant change in the nature of the corporation that occurred in this period. From 1890 to 1916 American capitalism transformed from a system of owner/manager enterprises operating in largely unregulated competitive markets to a system dominated by relatively few large, mostly non-owner-managed corporations in a regulated competitive market. ${ }^{82}$ In particular, although there were large-scale corporations before the Progressive Era, consolidation began only in the early 1890s and accelerated to a wave of consolidation by merger between 1898 and $1904 .^{83}$ The key legal change was New Jersey's adoption in 1890 of a new corporate law that permitted holding corporations. ${ }^{84}$ This enabled the consolidators to avoid the cumbersome 'trust' structures (in which shareholders contributed their shares to a trust in exchange for certificates of beneficial ownership) for the simpler holding company structure of parent and operating subsidiaries. The result was a wave of corporate migration to New Jersey, followed in the 1910 s by another migration to Delaware when New Jersey balked at further pro-management rule changes. ${ }^{85}$

The reaction to the emergence of the 'trust issue' from around 1896 onward was a chorus of calls for more regulation. For example, in 1906, Representative Martin of South Dakota defined a trust as 'a combination of corporations', identified the resulting 'evils' as 'overcapitalization . . . the tendency to monopoly, and . . . the destruction of individual enterprise and success', and called for remedial legislation that would combine 'publicity', 'free competition' and 'close Federal supervision or regulation'. ${ }^{86}$ One immediate result was the attempt by President Roosevelt to control the

some extent exempt from tax to shareholders. See Bank, above n. 6, at 533. But dividends were taxed to the extent that the individual rate exceeded the basic or normal rate, and the corporate rate was set higher than the normal rate from 1918, resulting in partial double taxation. See S.A. Bank, 'Corporate Managers, Agency Costs, and the Rise of Double Taxation' (2002) 44 Wm \& Mary L Rev 167, 181-182 (discussing the historical evolution of double taxation).

82 See M.J. Sklar, The Corporate Reconstruction of American Capitalism, 1890-1916 (CUP, New York, 1988). For background, see generally A.D. Chandler, Jr., The Visible Hand: The Managerial Revolution in American Business (Belknap Press, Cambridge, Mass., 1977).

83 Sklar, above n. 82, at 45-46 and n.4 (noting that little further concentration took place between 1904 and 1954).

${ }^{84}$ See Act of 21 Apr. 1896, ch. 185, 1896 NJ Law 309-310 \$ (9)(104) ; L. Steffens 'New Jersey: A Traitor State: Part II-How She Sold Out to the United States' (1905) 25 McClure's Mag. 41.

${ }^{85}$ For the classic debate on whether this was a 'race to the bottom' or a 'race to the top', see W.L. Cary, 'Federalism and Corporate Law: Reflections Upon Delaware' (1974) 83 Yale LJ 663; R.K. Winter, Jr., 'State Law, Shareholder Protection, and the Theory of the Corporation' (1996) 6 J Legal Stud 251.

8640 Cong. Rec. 1849-1851 (1906) (statement of Rep. Martin). 
trusts by using the Sherman Antitrust Act of 1890, which led to the Supreme Court ultimately breaking up the Standard Oil Company, though holding at the same time that only 'unreasonable' restraints of trade were illegal. ${ }^{87}$

Roosevelt was not opposed to the growth of big business; unlike the Populists, he did not believe in turning the clock back to a 'golden age' of small producers. But he did favour federal regulation. In his 1907 message to Congress Roosevelt declared:

I am in no sense hostile to corporations. This is an age of combination, and any effort to prevent all combination will be not only useless, but in the end vicious ... We should, moreover, recognize in cordial and ample fashion the immense good effected by corporate agencies ... . The corporation has come to stay. ${ }^{88}$

But the following year, he also stated:

I strongly advocate that instead of an unwise effort to prohibit all combinations, there shall be substituted [for the Sherman Act] a law which shall expressly permit combinations which are in the interest of the public, but shall at the same time give to some agency of the National Government full power of control and supervision over them. ${ }^{89}$

Roosevelt's first concrete proposal was for federal incorporation. ${ }^{90}$ The Hepburn Bill, introduced in 1908, would have allowed corporations voluntarily to register with a federal office. ${ }^{91}$ The Bill failed, however, because of Republican opposition to such an expansion of executive branch power. If the Federal government registered corporations, it could also de-register them. ${ }^{92}$ Ultimately, these concerns led to the Clayton Antitrust Act of 1914 and the establishment of the Federal Trade Commission. ${ }^{93}$

The same concerns regarding trusts are reflected in the debates over the corporate tax, which was seen by both supporters and opponents as a regulatory measure. ${ }^{94}$ Kornhauser focused primarily on the publicity feature of the tax, but this was not its only regulatory aspect-both supporters and opponents saw the tax also as having the potential to restrict managerial

87 Standard Oil Co $v$ United States 221 US 1 (1911); see also United States $v$ AmTobacco Co 221 US 106, 179 (1911) (establishing a 'rule of reason' standard for interpreting the Sherman Act).

8842 Cong. Rec. 68 (1907) (statement of Pres. Roosevelt).

8943 Cong. Rec. 17 (1908) (statement of Pres. Roosevelt).

9042 Cong. Rec. 70 (1907) (statement of Pres. Roosevelt).

91 HR19745, 60th Cong., reprinted in An Act to Regulate Commerce, Etc.: Hearings on House Bill 19745 Before Subcomm. No. 3 of the House Comm. on the Judiciary, 60th Cong. 3-6 (1908).

92 Kornhauser, above n. 26, at 67.

93 Ibid.

${ }^{94}$ Ibid., at 62-63. 
power directly. ${ }^{95}$ Thus Senator Root, the principal drafter of the tax on the Senate side, spoke about the accumulation of wealth in the hands of corporations as a principal reason for the tax. ${ }^{96}$ Senator Newlands likewise supported the tax because 'there was no reason why the great combinations monopolizing these industries should not pay some part of the national expenses'. ${ }^{97}$ Similarly, Senator Owen stated that ' $[\mathrm{t}]$ he most important need of the people of the United States of this generation requires the abatement of the gigantic fortunes being piled up by successful monopoly'. ${ }^{98}$ And Senator Cummins, an opponent of the tax, likewise spoke about 'the new force entering American life and American business' which is 'a prelude to industrial commercial slavery unless the Government intervenes with its strong arm'.99 Senator Cummins opposed the tax because it applied to all corporations, rather than just to the great combinations, which he thought should be taxed more heavily. ${ }^{100}$ Senator Clapp was similarly concerned about the trusts but argued that the proposed tax did not address the problem because of the exemption of dividends paid to holding corporations. ${ }^{101}$ Senator Cummins's solution was to tax the trusts more heavily:

[I]f a company is organized for the purpose of consolidating a dozen other companies with a view to controlling the business in which those companies are engaged for the purpose of being able to direct through a single board the management of the entire field of industry ... aside from the contravention of public policy involved in such an organization the privilege enjoyed is of priceless value, and instead of being taxed at 2 per cent on the net earnings it ought to be

95 For a discussion of publicity, see ibid., at 69-82.

9644 Cong. Rec. 4003 (1909) (statement of Sen. Root).

9744 Cong. Rec. 3761 (1909) (statement of Sen. Newlands). Newlands supported in particular taxing all industries benefiting from the tariff: 44 Cong. Rec. 3762 (1909); 44 Cong. Rec. 4049 (1909) (statement of Sen. Newlands) (proposing an exemption for small corporations so as to "confine our taxation to these great combinations of capital whose profits have been enormous, whose ability to bear is greater than that of any other class of the community, and whose abuses have awakened the attention of the country and demand legislative cure'.).

9844 Cong. Rec. 3950 (1909) (statement of Sen. Owen). He stated that corporate wealth of publicly traded corporations amounted to one-third of national wealth: ibid., see also 44 Cong. Rec. 4000-4001 (1909) (statement by Sen. Bourne) (supporting the tax because the tendency of business to consolidate requires strengthening the government's ability to regulate).

9944 Cong. Rec. 3965 (1909) (statement of Sen. Cummins).

10044 Cong. Rec. 3978 (1909) (statement of Sen. Cummins).

10144 Cong. Rec. 4009-4010 (1909) (statement of Sen. Clapp) ('[t] he plain invitation, the plain effect of this provision is to encourage the organization of the very kind of corporations, great, powerful, overshadowing, absorbing industries, absorbing industrial life and industrial affairs, by holding out to them immunity from taxation'); see also 44 Cong. Rec. 4230 (1909) (statements of Sen. Dolliver) (focusing on the trust problem as well). Senator Davis, by contrast, thought the solution to 'the corporations of the country invading every avenue of business and trade' was 'that if we can not tax all the corporations, we should tax just as many of them as we can': 44 Cong. Rec. 4036 (1909). And Senator Aldrich pointed out that no corporation was exempt from the tax: 44 Cong. Rec. 4231 (1909). 


\section{Reuven S Avi-Yonah}

taxed at 10 or 15 per cent on the net earnings, that it ought to be taxed so heavily that such companies would become not only unfashionable but unprofitable as well. ${ }^{102}$

The principal reason for the difference between the 1894 tax, a tax on shareholders, and the 1909 tax, a tax on management, was thus the rise of the great trusts in the period between 1896 and $1904 .{ }^{103}$ By 1909, the trust problem was perceived as the most serious issue facing the country. ${ }^{104}$ Some Democrats would have liked to turn back the clock and outlaw the trusts, but the majority preferred to follow President Roosevelt and regulate them. ${ }^{105}$ A primary vehicle for such regulation was the corporate tax, in part because of its publicity feature, but in part because, many claimed during the Congressional debate, the power to tax is the 'equivalent of the power to destroy'. ${ }^{106}$ To tax the powerful trusts was seen as the beginning of a federal power to regulate and potentially destroy them. That was the fundamental rationale for enacting the corporate income tax.

10244 Cong. Rec. 4232 (1909) (statement of Senator Cummins). Senator Newlands made similar arguments: 44 Cong. Rec. 4233 (1909) (statement of Sen. Newlands).

103 By 1900, J.D. Rockefeller had created the Standard Oil Company and capitalised it at $\$ 122$ million. The following year J.P. Morgan created US Steel in a \$1.4 billion transaction. Between 1898 and 1901, the capitalisation of mergers totalled \$5.4 billion and 2,274 firms were merged out of existence: Sklar, above n. 83, at 45-46.

104 See H.L. Wilgus, 'Need of a National Incorporation Law' (1904) 2 Mich L Rev 358 (1904) (discussing the nature and scope of the trust problem).

105 See Kornhauser, above n. 26, at 63-64 (discussing the political positions on the trusts and the government's preference for regulation).

106 See, eg, 44 Cong. Rec. 3977 (Sen. Cummins, referring to McCulloch v Maryland 17 US 316 (1819). 